\title{
The effect of low level leukocytospermia on oxidative stress markers in infertile men
}

\author{
Saad Alshahrani ${ }^{1,2}$, Ashok Agarwal $^{1,3^{*}}$, Mourad Assidi $^{3,4}$, Adel M. Abuzenadah $^{3,4}$, Ahmet Ayaz ${ }^{1}$, Rakesh Sharma ${ }^{1}$ \\ From 2nd International Genomic Medical Conference (IGMC 2013) \\ Jeddah, Kingdom of Saudi Arabia. 24-27 November 2013
}

\section{Background}

Leukocytospermia is defined as presence of $\geq 1 \times 106$ $\mathrm{WBC} / \mathrm{mL}$ of the seminal ejaculate. The World Health Organization (WHO) recommends peroxidase staining as the standard method for the detection of semen leukocytes $[1,2]$. The incidence of leukocytospermia ranges from 10 $20 \%$ among infertile men. Both morphologically abnormal spermatozoa and leukocytes produce reactive oxygen species (ROS). The polymorphonuclear neutrophils and macrophages are the main components of seminal leukocytes which can generate significantly higher ( $>100$-fold) quantities of ROS, overwhelming the ROS-scavenging mechanisms in seminal plasma and resulting in oxidative stress and damage to spermatozoa. The presence of very few activated leukocytes can produce a detectable amount of ROS $[3,4]$. Therefore, even a very low number of leukocytes in the sperm suspension may influence the integrity of sperm and, consequently, the outcome of assisted reproduction treatment [5]. Leukocytes contributed directly to ROS production and release and indirectly through the leukocyte-stimulated sperm. Such stimulation may be via direct contact or mediated by soluble products released by the leukocytes. The goal of our study was to assess the effect of low level leukocytospermia on semen quality and oxidative stress markers in infertile men.

\section{Materials and methods}

In this prospective study, 211 infertile patients with no history of genital tract infections or varicocele were included. Semen samples were examined for sperm concentration, motility, seminal leukocyte levels (Endtz test) [2], reactive oxygen species (ROS) by chemiluminescence assay, and sperm DNA damage by TUNEL test. Patients were divided into 3 groups based on their seminal leukocyte levels. Group 1: no seminal leukocytes (n = 153); group 2: low level leukocytospermia (0.1 -1 X $106 \mathrm{WBC} / \mathrm{mL} ; \mathrm{n}=22$ ); and group 3: leukocytospermia $(>1 \times 106 \mathrm{WBC} / \mathrm{mL} ; \mathrm{n}=36)$.

Table 1 Semen parameters and its association with leukocytospermia

\begin{tabular}{lccc}
\hline Parameters & \multicolumn{3}{c}{ Seminal leukocytes $\left(\mathrm{X} 10^{6} \mathrm{WBC} / \mathrm{mL}\right)$} \\
\cline { 2 - 4 } & No leukocytes & $0.1-1 \mathrm{WBC}$ & $>1 \mathrm{WBC}$ \\
\hline Concentration $\left(\mathrm{X} 10^{6} / \mathrm{mL}\right)$ & $53.04 \pm 56.76$ & $69.04 \pm 80.72$ & $39.35 \pm 39.98$ \\
\hline Motility (\%) & $48.37 \pm 17.42$ & $47.33 \pm 25.74$ & $49.23 \pm 19.56$ \\
\hline Normal morphology (\%) & $3.42 \pm 3.12$ & $3.56 \pm 3.16$ & $4.14 \pm 3.79$ \\
\hline ROS (RLU/ sec) & $116.7(49 ; 550.3)$ & $944.8(127 ; 3315.4)^{\mathrm{a}}$ & $61286.8(6905 ; 234876)^{\mathrm{a}, \mathrm{b}}$ \\
\hline DNA damage (\%) & $19.89 \pm 17.31$ & $26.47 \pm 19.64^{\mathrm{a}}$ & $24.60 \pm 17.47$ \\
\hline
\end{tabular}

Results are presented as mean \pm SD for all the parameters except ROS which is presented as median $\left(25^{\text {th }} ; 75^{\text {th }}\right.$ percentile).

${ }^{\mathrm{a}} P<0.05$ statistically significant compared to non leukocytospermic group.

${ }^{\mathrm{b}} P<0.05$ statistically significant compared to low level leukocytospermic group.

\footnotetext{
* Correspondence: agarwaa@ccf.org

${ }^{1}$ Center for Reproductive Medicine, Cleveland Clinic, Cleveland, Ohio 44195,

USA

Full list of author information is available at the end of the article
}

\section{() Biomed Central}

(c) 2014 Alshahrani et al; licensee BioMed Central Ltd. This is an Open Access article distributed under the terms of the Creative Commons Attribution License (http://creativecommons.org/licenses/by/2.0), which permits unrestricted use, distribution, and reproduction in any medium, provided the original work is properly cited. 


\section{Results}

22 patients (10\%) had high and $36(18.3 \%)$ had low seminal leukocytes levels (Table 1). Conventional semen parameters between the 3 groups were similar. Patients with low level leukocytospermia had significantly higher levels of ROS ( $\mathrm{P}=0.001)$ and sperm DNA damage $(\mathrm{P}<0.05)$ compared to non leukocytospermic group. There was no significant difference in ROS levels between the two groups of leukocytospermia (groups 2 and 3 ).

\section{Conclusions}

Patients presenting with low levels of leukocytes have a high oxidative stress. Although these patients are not categorised as leukocytospermic by current WHO guidelines, however these men may benefit by treatment with antibiotics or antioxidant supplements to reduce ROS induced sperm DNA damage and improve therefore their chances of fertility.

\section{Authors' details}

${ }^{1}$ Center for Reproductive Medicine, Cleveland Clinic, Cleveland, Ohio 44195 USA. ${ }^{2}$ Salman Bin Abdulaziz University, College of Medicine, Saudi Arabia.

${ }^{3}$ Center of Excellence in Genomic Medicine Research, KAU, Saudi Arabia.

${ }^{4}$ KACST Technology Innovation Center for Personalized Medicine, King

Abdulaziz University, Jeddah, Saudi Arabia.

Published: 2 April 2014

\section{References}

1. World Health Organization: WHO Laboratory manual for the examination of human semen and sperm-cervical mucus interaction. Cambridge, Cambridge University Press; 4th 1999.

2. World Health Organization: WHO laboratory manual for the examination and processing of human semen. Geneva, Switzerland; Fifth 2010.

3. Plante M, de Lamirande E, Gagnon C: Reactive oxygen species released by activated neutrophils, but not by deficient spermatozoa, are sufficient to affect normal sperm motility. Fertil Steril 1994, 62:387-393.

4. Sharma R, Pasqualotto F, Nelson D, Thomas A, Agarwal A: Relationship between seminal white blood cells counts and oxidative stress in men treated at an infertility clinic. J Androl 2001, 22:575-583.

5. Henkel R, Kierspel E, Stalf T, Mehnert C, Menkveld R, Tinneberg HR, Schill WB, Kruger TF: Effect of reactive oxygen species produced by spermatozoa and leukocytes on sperm functions in nonleukocytospermic patients. Fertil Steril 2005, 83:635-642.

\section{doi:10.1186/1471-2164-15-S2-P56}

Cite this article as: Alshahrani et al:: The effect of low level leukocytospermia on oxidative stress markers in infertile men. BMC Genomics 2014 15(Suppl 2):P56.

\section{Submit your next manuscript to BioMed Central and take full advantage of:}

- Convenient online submission

- Thorough peer review

- No space constraints or color figure charges

- Immediate publication on acceptance

- Inclusion in PubMed, CAS, Scopus and Google Scholar

- Research which is freely available for redistribution

Submit your manuscript at www.biomedcentral.com/submit
C Biomed Central 